\title{
PENGARUH PEMAHAMAN PERATURAN PAJAK, PELAYANAN FISKUS, PERSEPSI EFEKTIVITAS SISTEM PERPAJAKAN TERHADAP KEMAUAN MEMBAYAR PAJAK (Studi Empiris Pada Kantor Pelayanan Pajak Pratama Jayapura)
}

\author{
Rachmad Putra Ramadhan ${ }^{1}$ \\ Amdputra77@gmail.com \\ Dr. Syaikhul Fallah., SE., M.Si ${ }^{2}$ \\ Mariolin Sanggenafa, SE., M.SA., $\mathbf{A k}^{3}$ \\ Jurusan Akuntansi, Fakultas Ekonomi dan Bisnis Universitas Cenderawasih
}

\begin{abstract}
This study aims to analyze and provide empirical evidence of the influence of independent variables, namely the understanding of tax regulations, tax services, and perceptions of the effectiveness of the tax system on the dependent variable of willingness to pay personal taxpayer in Jayapura City. Sampling method was used in this study is nonprobability sampling method with purposive sampling technique (intentional sampling) to determine the desired on target respondents. Respondents who are sampled in this study are taxpayers of individuals registered and classified as effective taxpayers in KPP Pratama Jayapura totaling 100 people. Data analysis was used multiple linear regression analysis with SPSS 16.0 application. The result of this research shows that the variable of understanding of tax regulation does not affect the willingness of paying tax, the perception of tax system effectiveness does not affect the willingness to pay the tax, then the tax service variable affect the willingness to pay taxes.
\end{abstract}

Keyword : understanding of tax regulations, tax services, perceptions of tax system effectiveness, willingness to pay taxes..

\section{PENDAHULUAN}

Sektor pajak merupakan penggerak dalam pengembangan fasilitas publik yang bersifat umum. Bersifat umum disini dimaksudkan dapat digunakan membantu masyarakat serta membantu dalam pembiayaan kepentingan negara. Tanpa disadari kita sudah merasakan dampak dari penerimaan pendapatan negara yang berasal dari sektor pajak tersebut. Peran sektor pajak dalam pengembangan fasilitas publik diantaranya pembangunan rumah sakit, jalan raya, jembatan, taman kota, kantor kantor instansi pemerintahan dan fasilitas infrastruktur lainnya yang dapat membantu masyarakat luas. Bukti dari hasil pembangunan fasilitas umum tadi merupakan bentuk realisasi pajak yang berjalan dengan baik. Selain digunakan untuk pembangunan fasilitas umum, pendapatan negara juga digunakan untuk kepentingan lainnya seperti subsidi, serta digunakan untuk membayar gaji pegawai negeri dan orang - orang yang bekerja untuk pemerintah.

Pemahaman mengenai pajak yang minim menyebabkan masyarakat atau wajib pajak tidak taat dalam membayar pajak. Faktor mengenai pemahaman tentang pajak ini dikarenakan masyarakat merasa tidak adanya bukti nyata timbal balik secara nyata dari membayar pajak. Kesadaran masyarakat sebagai wajib pajak harus lebih ditingkatkan. Pemahaman tentang pajak harus diberikan

\footnotetext{
${ }^{1}$ Alumni Jurusan Akuntansi FEB Uncen

${ }^{2}$ Dosen Jurusan Akuntansi FEB Uncen

3 Dosen Jurusan Akuntansi FEB Uncen
} 
sejak awal kepada pelajar, masyarakat ataupun pelaku pengusaha UMKM (Usaha Mikro, Kecil, dan Menengah). Semakin tinggi tingkat pemahaman masyarakat tentang pajak, maka akan semakin tinggi pula inisiatif masyarakat untuk membayar pajak. Setelah mengetahui dan paham mengenai pentingnya membayar pajak, wajib pajak akan mengetahui pula tentang peraturan perpajakan yang berlaku dan memiliki sanksi. Sanksi perpajakan dapat berupa sanksi administrasi dan sanksi pidana. Jika wajib pajak telah mengetahui tentang hal ini, berarti wajib pajak telah benar - benar paham mengenai pentingnya membayar pajak. Dari semua perihal tentang kewajiban masyarakat untuk mengetahui dan memahami tentang ketetapan peraturan dan sanksi pajak, adalah bertujuan agar tidak ada lagi alasan wajib pajak tidak melaksanakan kewajibannya.

Papua adalah sebuah provinsi di Indonesia yang merupakan salah satu provinsi terkaya dengan berbagai macam keanekaragamannya. Dengan berbagai macam keanekaragaman ini, provinsi papua juga memiliki berbagai macam sumber jasa yang dapat dikenakan tarif pajak. Penerimaan pajak dapat diterima dari berbagai sumber, misalnya mulai dari sektor pariwisata hingga kegiatan usaha dan jasa yang dapat dikenakan pajak. Oleh karena itu, sangat penting untuk menumbuhkan kemauan wajib pajak untuk membayarkan kewajiban perpajakannya.

Dari penjelasan diatas maka peneliti ingin untuk mengangkat topik penelitian mengenai variabel pemahaman peraturan pajak, pelayanan fiskus, persepsi efektivitas sistem perpajakan, dan kemauan membayar pajak dengan alasan peneliti ingin kembali mengetahui mengenai tingkat kemauan membayar pajak WPOP di kota Jayapura. Kemudian peneliti juga ingin mengetahui perbandingan antara penelitian sebelumnya yang dilakukan di KPP Pratama Denpasar Timur dengan penelitian yang akan dilakukan saat ini di KPP Pratama Jayapura. Serta peneliti juga ingin mengkaji kembali hasil penelitian ini dengan penelitian - penelitian sebelumnya yang dilakukan di kota Jayapura agar penelitian ini dapat menyimpulkan hasil apakah tingkat kemauan membayar pajak oleh WPOP di KPP Pratama Jayapura meningkat ataukah menurun di tahun 2018.

Pada penelitian ini, peneliti akan mencoba meneliti tentang bagaimana pengaruh pemahaman tentang peraturan pajak, pelayanan fiskus, serta persepsi atas efektivitas sistem perpajakan terhadap kemauan membayar pajak di KPP Pratama yang berada di kota Jayapura. Perumusan masalah dalam penelitian ini adalah 1). Apakah pemahaman tentang peraturan pajak berpengaruh terhadap kemauan membayar pajak ?, 2). Apakah pelayanan fiskus berpengaruh terhadap kemauan membayar pajak ?, dan 3). Apakah persepsi atas efektivitas system perpajakan berpengaruh terhadap kemauan membayar pajak ?. Dengan demikian tujuan penelitian ini adalah 1). Untuk memberi bukti empiris pengaruh pemahaman tentang peraturan pajak terhadap kemauan membayar pajak WPOP di KPP Pratama Jayapura, 2). Untuk memberi bukti empiris pengaruh pelayanan fiskus terhadap kemauan membayar pajak WPOP di KPP Pratama Jayapura. dan 3). Untuk memberi bukti empiris pengaruh persepsi atas efektivitas system perpajakan terhadap kemauan membayar pajak WPOP di KPP Pratama Jayapura. Oleh karena itu, diharapkan penelitian ini mampu memberikan informasi dan masukkan yang berguna dibidang perpajakan bagi masyarakat dan para fiskus bahwa kemauan pembayaran kewajiban perpajakan dapat membantu pelaksanaan pembangunan nasional dan meningkatkan kesejahteraan masyarakat secara menyeluruh. Serta, mampu menjadi bahan referensi bagi pengembangan ilmu pengetahuan dan pertimbangan perbandingan dalam penyusunan penelitian bagi peneliti selanjutnya mengenai pengaruh pemahaman tentang peraturan pajak, pelayanan fiskus, dan persepsi atas efektivitas system perpajakan terhadap kemauan membayar pajak. 


\section{TINJAUAN PUSTAKA}

\subsection{Teori Atribusi}

Teori atribusi adalah teori yang dikemukakan pertama kali oleh (Newcomb \& Heider, 1958). Teori atribusi merupakan teori yang menjelaskan tentang perilaku seseorang dan menjelaskan mengenai proses bagaimana seseorang menentukan penyebab dan motif tentang perilaku orang lain yang menjadi objek. Atau dengan kata lain teori ini menjelaskan proses dimana seseorang menarik kesimpulannya mengenai faktor - faktor yang mempengaruhi perilaku orang lain. Dari teori ini, perilaku yang dimaksud adalah berhubungan dengan sikap dan karakteristik individu.

\subsection{Pemahaman Peraturan Perpajakan}

Pemahaman Wajib Pajak terhadap peraturan perpajakan adalah cara Wajib Pajak dalam memahami peraturan perpajakan yang telah ada (Hardiningsih dan Yulianawati, 2011). Pemahaman dimaksudkan disini adalah kemampuan seseorang untuk menangkap makna atau artian tertentu suatu objek ataupun bahan pembelaja-ran yang sedang dipelajari. Menurut Poesprodjo (1987:52-53) bahwa pemahaman bukan kegiatan berpikir semata, melainkan pemindahan letak dari dalam berdiri disituasi atau dunia orang lain.

\subsection{Pelayanan Fiskus}

Pada era sekarang ini, pelayanan berkaitan dengan pemberian kepuasan terhadap seseorang (wajib pajak). Pengertian mengenai pelayanan itu sendiri adalah merupakan sebuah proses pemenuhan kebutuhan melalui aktivitas seseorang secara langsung dengan cara melayani atau membantu orang tersebut untuk mengurus dan menyiapkan segala keperluan yang dibutuhkan orang tersebut guna mencapai tujuan yang diinginkan. Sementara itu fiskus atau aparatur pajak atau petugas pajak adalah orang atau badan yang bertugas untuk melakukan pemungutan iuran wajib masyarakat kepada negara (pajak). Jadi, pelayanan fiskus adalah sebuah proses cara atau kegiatan seorang petugas pajak untuk membantu wajib pajak memenuhi kebutuhannya mengurus dan menyiapkan segala sesuatu yang diperlukan oleh wajib pajak.

\subsection{Persepsi Efektivitas Sistem Perpajakan}

Persepsi adalah merupakan proses aktivitas seseorang dalam memberikan kesan, penilaian, pendapat, memahami, mengorganisir, menafsirkan yang memungkinkan situasi, peristiwa yang dapat memberikan kesan perilaku yang positif atau negatif (Robins, Spranca, \& Mendelsohn, 1996). Persepsi dapat dinyatakan sebagai suatu proses pengorganisasian, pengintepretasian terhadap stimulus oleh organisasi atau individu sehingga merupakan suatu yang berarti dan merupakan aktivitas integrated dalam diri individu. (Widayati dan Nurlis, 2010).

\subsection{Kemauan Membayar Pajak}

Kemauan adalah sebuah dorongan yang berasal dari dalam diri seseorang, berdasarkan pertimbangan, pemikiran, dan perasaan secara sadar yang timbul agar seseorang dapat melakukan suatu kegiatan untuk tercapainya tujuan tertentu. Sedangkan, kemauan membayar merupakan suatu nilai dimana seseorang rela untuk membayar, mengorbankan atau menukarkan sesuatu untuk memperoleh barang dan jasa (Widaningrum, 2007 dalam Widayati dan Nurlis, 2010).

Berdasarkan definisi di atas, kemauan membayar pajak dapat diartikan sebagai suatu nilai yang rela dikontribusikan oleh seseorang (yang ditetapkan dengan peraturan) yang digunakan untuk membiayai pengeluaran umum negara dengan tidak mendapat jasa timbal balik (kontraprestasi) secara langsung (Ratung \& Adi, 2009) 


\subsection{Pengembangan Hipotesis}

\subsubsection{Pengaruh Pemahaman Peraturan Pajak Terhadap Kemauan Membayar Pajak}

Pemahaman tentang peraturan perpajakan merupakan sebuah penalaran dan penangkapan makna tentang peraturan perpajakan. Yang diperoleh dengan mempelajari dan nmengamati sebuah kejadian atau sebuah informasi. Masyarakat hendaknya memiliki pengetahuan dan pemahaman tentang peraturan peraturan perpajakan yang berlaku, karena untuk memenuhi kewajiban perpajakan, wajib pajak harus mengetahui tentang informasi atau gambaran umum tentang pajak terlebih dahulu. Tanpa adanya pengetahuan dan pemahaman peraturan perpajakan yang dimiliki masyarakat, maka kemauan masyarakat untuk membayar dan melunasi pajaknya tidak akan mungkin.

Mengetahui dan memahami mengenai peraturan perpajakan merupakan salah satu faktor penting agar para wajib pajak mau membayar pajak terhutangnya dengan baik dan benar. Dengan pemahaman yang dikuasai mengenai perpajakan, para wajib pajak akan mengerti mengenai pentingnya membayar pajak, langkah-langkah dan tahap prosedur yang dilakukan dalam membayar pajak. Informasi mengenai perpajakan dapat ditemukan dari berbagai banyak sumber, dari edukasi pajak disekolah, media cetak, atau bahkan dari jejaring media sosial pun tersedia berbagai info mengenai perpajakan. Setelah mengetahui dan memahami mengenai hal - hal yang terkait dengan pajak, diharapkan wajib pajak akan mampu menerapkan pemahamannya guna memunculkan kemauan untuk melunasi kewajiban perpajakan. Dengan adanya pemahaman mengenai perpajakan, akan mendukung atau mempengaruhi kemauan dalam membayar pajak.

Penelitian yang dilakukan oleh Fikriningrum \& Syafruddin (2012) menunjukkan hasil bahwa pengetahuan dan pemahaman peraturan perpajakan berpengaruh positif dan signifikan terhadap kemauan membayar pajak, hasil ini juga didukung oleh penelitian Fitriana (2012) yang menunjukkan bahwa variabel pemahaman tentang peraturan perpajakan mempunyai pengaruh yang signifikan terhadap kemauan membayar pajak. Dan yang terakhir penelitian oleh Nuzul (2015) hasil penelitiannys juga menunjukkan nilai thitung pada variabel pemahaman sebesar $(2,365)$ lebih besar dari ttabel $(1,98)$ maka dinyatakan terdapat pengaruh terhadap willingness to pay taxes/ kemauan membayar pajak.

Berdasarkan penjelasan teori mengenai Pemahaman Peraturan Perpajakan dan hasil penelitian terdahulu, maka dirumuskan hipotesis sebagai berikut :

\section{H1: Pemahaman Peraturan Perpajakan berpengaruh signifikan terhadap Kemauan Membayar Pajak.}

\subsubsection{Pengaruh Pelayanan Fiskus Terhadap Kemauan Membayar Pajak}

Fiskus atau aparatur pajak adalah petugas yang berperan membantu, mengurus, memandu ataupun menyiapkan segala keperluan yang dibutuhkan para wajib pajak dalam melakukan kegiatan pembayaran pajak. Pelayanan fiskus berpengaruh untuk mendorong kemauan wajib pajak untuk memenuhi pelunasan kewajiban perpajakan. Sebab, semakin meningkatnya kualitas pelayanan fiskus, semakin meningkat pula kemauan wajib pajak dalam membayar pajak terhutangnya. Begitu pula jika sebaliknya pelayanan fiskus yang buruk dapat mempengaruhi sikap wajib pajak dan akan memunculkan dampak kemalasan untuk memenuhi kewajiban perpajakannya.

Pelayanan fiskus yang baik dituntut dapat memberikan kepuasan kepada wajib pajak dengan tetap memenuhi batas standar pelayanan. Pelayanan fiskus yang baik harus secara terus - menerus dijalankan guna mempertanggungjawabkan kewajiban aparatur pajak yang selama ini dituntut agar menjalankan kinerja secara baik dan benar agar membantu kesulitan - kesulitan yang dialami oleh 
para wajib pajak. Apabila pelayanan jasa fiskus yang diberikan telah memenuhi harapan, maka pelayanan yang bermutu akan terwujud. Dengan pelayanan yang bermutu ini pula akan mengurangi kesenjangan yang terjadi pada kasus kurangnya kemauan membayar pajak. Semakin kecilnya kesenjangan akan memperkecil jumlah wajib pajak yang malas membayar pajak dan akan memaksimalkan kinerja pelayanan fiskus.

Dari hasil penelitian yang dilakukan oleh beberapa peneliti terdahulu diantaranya oleh Hardiningsih \& Yulianawati (2011) dalam penelitiannya menyatakan kualitas layanan berpengaruh positif terhadap kemauan membayar pajak. Kemudian Fikriningrum \& Syafruddin (2012) menyatakan dalam penelitiannya bahwa pelayanan fiskus berpengaruh positif dan signifikan terhadap kemauan membayar pajak. Pada penelitian Priscilla (2016) menunjukkan bahwa variabel kualitas pelayanan terhadap wajib pajak berpengaruh terhadap kemauan membayar pajak. Dan yang terakhir hasil penelitian oleh Nuzul (2015) juga menunjukkan nilai thitung pada variabel kualitas pelayanan pajak sebesar $(2,953)$ lebih besar dari ttabel $(1,98)$ maka dinyatakan terdapat pengaruh terhadap willingness to pay taxes.

Berdasarkan penjelasan teori mengenai pelayanan fiskus dan hasil dari penelitian terdahulu dapat dirumuskan hipotesis sebagai berikut :

\section{H2: Pelayanan Fiskus berpengaruh signifikan terhadap Kemauan Membayar Pajak.}

\subsubsection{Pengaruh Persepsi Efktivitas Sistem Perpajakan Terhadap Kemauan Membayar Pajak}

Persepsi efektifitas sistem perpajakan adalah bagaimana proses wajib pajak memberikan tanggapan dan menilai menurut persepsi dari dalam dirinya sendiri mengenai pengukuran yang menyatakan baik tidaknya sistem perpajakan yang sedang berjalan. Persepsi yang dimaksud adalah apakah sistem tersebut mempermudah wajib pajak atau sebaliknya malah mempersulit wajib pajak.

Di Indonesia sudah cukup banyak kebijakan - kebijakan dan kinerja - kinerja pemerintah sebagai aparatur pajak yang telah berusaha dalam meningkatkan kemauan membayar pajak. Kebijakan dan kinerja tersebut meliputi program - program yang telah coba dijalankan pemerintah demi mempermudah para wajib pajak untuk melakukan transaksi pajak. Diantaranya Adanya sistem pelaporan melalui e-SPT dan e-Filling, Pembayaran melalui e-Banking, Penyampaian SPT melalui drop box, peraturan perpajakan dapat diakses dengan lebih cepat melalui internet, dan pendaftaran NPWP yang dapat dilakukan secara online melalui e-Register dari website pajak. Kemajuan pesat yang dilakukan pemerintah dalam menyukseskan transaksi pajak bertujuan memudahkan para wajib pajak. Dengan adanya kemudahan dibidang perpajakan akan secara otomatis mendongkrak kemauan para wajib pajak membayarkan pajaknya.

Hasil analisis penelitian terdahulu yang dilakukan oleh Fikriningrum \& Syafruddin (2012) bahwa persepsi yang baik atas efektifitas sistem perpajakan berpengaruh positif dan signifikan terhadap kemauan membayar pajak. Lalu penelitian oleh Wijaya. RM. Sayid Fiska Kusuma (2014) menunjukkan dari tiga variable yang diteliti hanya variabel persepsi atas efektifitas sistem perpajakan yang berpengaruh terhadap kemauan membayar pajak. Kemudian penelitian Fitriana (2012) menunjukkan bahwa variabel persepsi efektifitas sistem perpajakan mempunyai pengaruh yang signifikan terhadap kemauan membayar pajak. Kemudian Nurlaela (2014) persepsi yang baik terhadap sistem perpajakan berpengaruh signifikan terhadap kemauan membayar pajak oleh wajib pajak. Dan terakhir Nuzul (2015) menunjukkan nilai thitung pada variabel efektifitas sistem perpajakan sebesar $(2,004)$ lebih besar dari ttabel $(1,98)$ maka dinyatakan terdapat pengaruh terhadap willingness to pay taxes. 
Berdasarkan penjelasan teori tentang persepsi atas efektifitas sistem perpajakan dan hasil dari penelitian terdahulu dapat dirumuskan hipotesis sebagai berikut :

H3: Persepsi Efektivitas Sistem Perpajakan berpengaruh signifikan terhadap Kemauang Membayar Pajak.

\subsection{Model Penelitian}

Dari hasil pengembangan hipotesis yang telah dikemukakan pada penelitian ini, maka dapat digambarkan model atau desain penelitian sebagai berikut:

Gambar 1

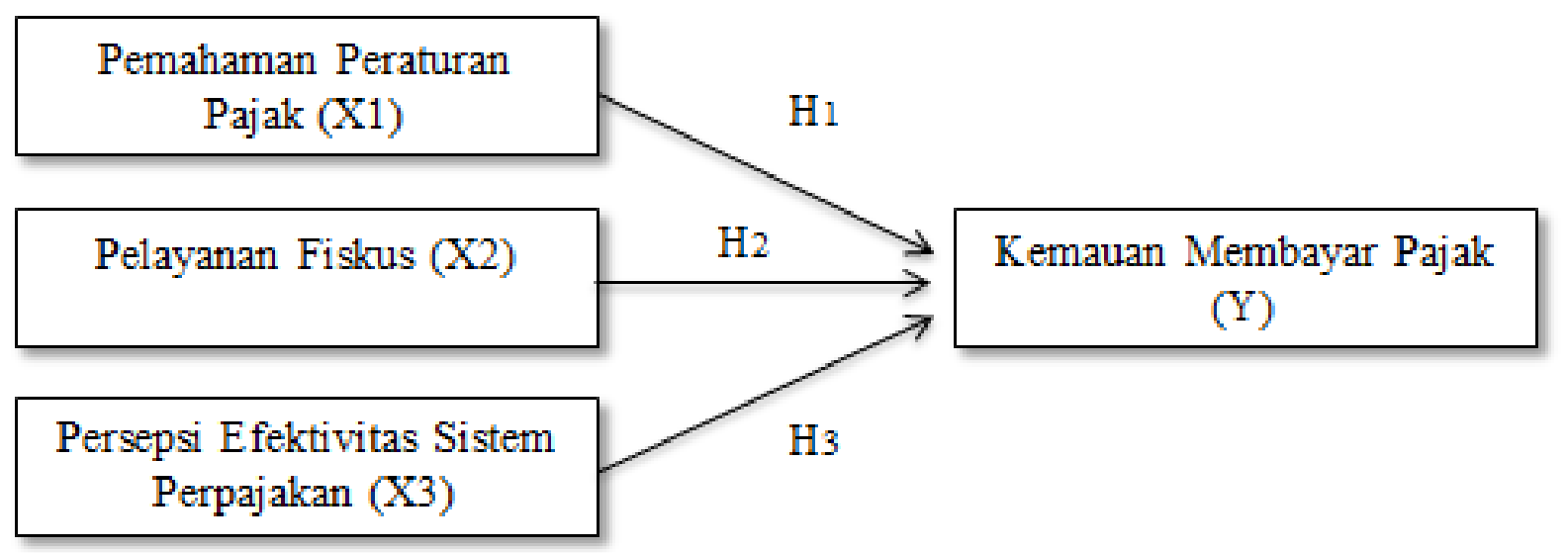

Sumber: Penulis (2018)

\section{METODE PENELITIAN}

\subsection{Jenis Penelitian}

Penelitian yang akan dilakukan pada penelitian ini adalah jenis penelitian kuantitatif, yaitu penelitian yang menekankan analisis datanya pada data - data numerical yang diolah dengan metode statistik dengan tujuan pengujian hipotesis. Penelitian kuantitatif ini dilakukan dengan bentuk asosiatif, yaitu penelitian yang bertujuan mengetahui pengaruh antara dua variabel atau lebih yang akan diteliti.

\subsection{Populasi dan Sampel Penelitian}

Populasi pada penelitian ini adalah para wajib pajak orang pribadi yang tercatat dan terdaftar di Kantor Pelayanan Pajak Pratama Jayapura, dengan syarat masih tergolong wajib pajak efektif. Pemilihan populasi ini dilakukan karena wajib pajak orang pribadi efektif merupakan wajib pajak yang tergolong baik dalam memenuhi kewajiban perpajakannya.

Sampel pada penelitian ini adalah beberapa wajib pajak orang pribadi yang terdaftar di Kantor Pelayanan Pajak Pratama Jayapura. Proses penentuan sampel yaitu menggunakan metode nonprobability sampling dengan teknik purposive sampling (pengambilan sampel secara disengaja) untuk menentukan target responden yang diinginkan. Kriteria penentuan sampel penelitian ini adalah wajib pajak orang pribadi yang efektif dan terdaftar di Kantor Pelayanan Pajak Pratama Jayapura dan wajib pajak orang pribadi yang mengurus kewajiban perpajakannya sendiri. 


\subsection{Teknik Dan Alat Pengumpulan Data}

Teknik pengumpulan data yang digunakan dalam penelitian ini adalah dengan menggunakan metode observasi non participant dan metode kuesioner. Teknik pengumpulan data dengan metode observasi non partisipan adalah keadaan dimana seorang observator atau orang yang melakukan observasi tidak ikut di dalam kehidupan orang yang akan diobservasi, dan secara terpisah berkedudukan dan berperan hanya sebagai seorang pengamat. Dalam hal ini observator hanya bertindak sebagai penonton saja tanpa harus ikut terjun langsung ke lapangan.

Kemudian untuk teknik pengumpulan data menggunakan metode kuisioner, pada metode ini pertanyaan kuesioner harus berkaitan dengan data demografi responden serta opini atau tanggapan yang berkaitan dengan pemahaman peraturan perpajakan, pelayanan fiskus, persepsi efektivitas sistem perpajakan, dan kemauan membayar pajak. Kemudian penjelasan pada petunjuk dan pertanyaan kuesioner dibuat sederhana dan sejelas mungkin untuk memudahkan pengisian jawaban bagi responden.

Kuesioner pada penelitian ini diukur dengan menggunakan Skala Likert dengan skala lima point. Skala Likert digunakan untuk mengukur sikap, pendapat, dan resepsi seseorang atau sekelompok orang tentang suatu fenomena sosial. Pilihan atau opsi alternative pada butir pertanyaan yang digunakan antara lain : (1) STS = "Sangat Tidak Setuju", (2) TS = "Tidak Setuju", (3) R = "Ragu", (4) $\mathrm{S}=$ "Setuju", dan (5) SS = "Sangat Setuju".

\subsection{Definisi Operasional}

Dalam penelitian ini terdapat 3 (tiga) variabel independen yaitu Pemahaman Peraturan Perpajakan (X1), Pelayanan Fiskus (X2) dan Persepsi Efektivitas Sistem Perpajakan (X3). Terdapat 1 (satu) variabel dependen yaitu Kemauan Membayar Pajak (Y). Berikut ini penjelasan dari masingmasing variabel:

\subsubsection{Pemahaman Peraturan Perpajakan}

Dengan bertambahnya pemahaman oleh wajib pajak akan mememunculkan kesadaran bahwa pentingnya membayar pajak bagi kepentingan masyarakat dan negara dengan begini tingkat kemauan membayar pajak akan menjadi semakin tinggi. Tingginya tingkat pemahaman tentang peraturan pajak akan mendorong para wajib pajak dalam menjalankan kewajibannya, dengan begitu akan timbulnya rasa suka rela dari dalam diri individu yang akan menyebabkan kemauan membayar pajak sesuai dengan ketentuan perpajakan. Berikut Indikator dalam peneliti ini yang merupakan replikasi dari kuesioner penelitian Nuzul (2015) yaitu : a). Kepemilikan NPWP dengan melakukan pendaftaran pada kantor pajak dan sesuai dengan domisili, b). Pengetahuan dan pemahaman mengenai hak dan kewajiban sebagai wajib pajak, c). Pengetahuan dan pemahaman mengenai sanksi administrasi, d). Pengetahuan dan pemahaman mengenai tariff penghasilan tidak kena pajak, e). Mengetahui dan memahami peraturan pajak melalui sosialisasi, dan f). mengetahui dan memahami peraturan pajak melalui training pajak yang mereka ikut.

\subsubsection{Pelayanan Fiskus}

Pelayanan dari aparatur pajak yang berhubungan langsung harus terus menjaga sopan santun dan perilaku, ramah, tanggap, cermat dan cepat dalam membantu kebutuhan dan keperluan yang berkaitan dengan wajib pajak. Petugas fiskus juga harus mau mendengarkan dengan baik apapun keluhan atau kritik tambahan mengenai pajak yang disampaikian oleh wajib pajak. Hal ini bertujuan meningkatkan kinerja perpajakan sekaligus meningkatkan rasa nyaman wajib pajak agar muncul kemauan untuk kembali dan datang ke kantor pajak membayarkan kewajiban perpajakannya. Berikut 
ini indikator-indikator dari pelayanan fiskus yaitu: a). prosedur pelayanan, b). organisasi, c). sumber daya manusia, dan d). sarana dan prasarana.

\subsubsection{Persepsi Efektivitas Sistem Perpajakan}

Salah satu pemanfaatan pajak adalah pembangunan fasilitas umum yang dijalankan guna memenuhi kebutuhan masyarakat. Dengan adanya persepsi yang baik dari masyarakat selaku wajib pajak atas efektifitas sistem perpajakan akan berpengaruh terhadap kemauan membayar pajak. Hubungan yang diciptakan baik oleh aparatur pajak di mata masyarakat selaku wajib pajak akan berdampak pada terbentuknya sikap wajib pajak yang dapat mempengaruhi untuk kemauan membayar pajak. Berikut ini adalah indikator dari persepsi efektivitas system perpajakan menurut Nuzul (2015):

a. Adanya system pelaporan melalui e-SPT dan e-filling, wajib pajak dapat melaporkan pajak secara lebih mudah dan cepat.

b. Pembayaran melalui e-banking yang memudahkan wajib pajak dalam melakukan pembayaran dimana dan kapan saja.

c. Penyampaian SPT melakui drop box yang dapat dilakukan di berbagai tempat, tidak harus di KPP tempat wajib pajak terdaftar.

d. Peraturan perpajakan dapat diakses dengan lebih cepat melalui internet tanpa harus menunggu adanya pemberitahuan dari KPP.

e. Pendaftaran NPWP yang dapat dilakukan secara online melalui e-register dari website pajak untuk memudahkan wajib pajak memperoleh NPWP.

\subsubsection{Kemauan Membayar Pajak}

Kemauan membayar pajak adalah suatu tindakan membayar pajak yang keluarkan berupa nilai kewajiban (yang ditetapkan dengan peraturan) oleh seseorang dengan ikhlas tanpa adanya unsur paksaan digunakan untuk membiayai pengeluaran umum negara dengan tidak mendapat jasa timbal balik (kontraprestasi) secara langsung. Pencapai target pajak sangat perlu ditumbuhkan secara terus menerus demi memenuhi pelunasan kewajiban perpajakan sesuai dengan ketentuan yang berlaku. Kesediaan wajib pajak untuk memenuhi kewajiban perpajakannya sesuai dengan aturan yang berlaku jika sudah terwujud dan berjalan dengan baik berarti menunjukkan bahwa tingkat kemauan membayar pajak sudah tergolong cukup besar. Dengan melihat pada beberapa indikator berikut ini:
a. Jumlah pajak yang tidak memberatkan, wajib pajak akan membayarkan pajaknya jika jumlah pajak sesuai dengan penghasilan wajib pajak dan tidak memberatkan wajib pajak.
b. Keadilan sanksi perpajakan, suatu sanksi dikatakan adil jika sanksi dilakukan sesuai dengan peraturan yang berlaku dan memberikan sanksi secara adil.
c. Pemanfaatan pajak yang tepat, wajib pajak akan melakukan pembayaran jika pajak digunakan sesuai dengan manfaatnya seperti pembangunan dan kesejahteraaan masyarakat.
d. Pelayanan yang baik, kemauan membayar pajak akan meningkat dengna pelayanan yang baik oleh aparat pajak.

\subsection{Teknik Analisis Data}

Pada penelitian ini akan digunakan Teknik analisis data yaitu analisis regresi linier berganda yang digunakan untuk menjelaskan keterkaitan antara variabel terikat dengan beberapa variabel bebas yang akan diolah menggunakan aplikasi SPSS 16.0 Dengan model persamaan sebagai berikut : 


$$
\mathrm{Y}=\boldsymbol{\beta 1 X 1}+\boldsymbol{\beta} 2 \mathrm{X} 2+\beta 3 \mathrm{X} 3+\varepsilon \ldots \ldots \ldots \ldots \ldots
$$

Keterangan :

$\mathrm{Y}=$ Kemauan Membayar Pajak

$\mathrm{X} 1=$ Pemahaman Tentang Peraturan Pajak

$\mathrm{X} 2$ = Pelayanan Fiskus

$\mathrm{X} 3=$ Persepsi Atas Efektivitas Sistem Perpajakan

$\beta \mathrm{x}=$ Koefisien Regresi

\section{HASIL PENELITIAN DAN PEMBAHASAN}

\subsection{Gambaran Umum Responden}

Pada penelitian ini kuesioner yang disebarkan berjumlah 105 buah dengan jumlah kuesioner yang tidak kembali sebanyak 2 buah, dan kuesioner yang tidak dapat diolah sebanyak 3 buah, dikarenakan kuesioner tersebut tidak terisi penuh sehingga kuesioner tersebut tidak dapat di analisis. Jadi, total jumlah kuesioner yang kembali dan dapat diolah ataupun dianalisis berjumlah 100 buah kuesioner, jumlah ini telah mencapai target yang telah ditetapkan guna kebutuhan data untuk penelitian ini.

\subsection{Statistik Deskriptif}

\section{Tabel 1}

\section{Statistik Deskriptif}

\begin{tabular}{|c|c|c|c|c|c|}
\hline \multicolumn{6}{|c|}{ Descriptive Statistics } \\
\hline & $\mathrm{N}$ & Minimum & Maximum & Mean & Std. Deviation \\
\hline $\mathrm{X} 1$ & 100 & 24 & 40 & 33.33 & 3.668 \\
\hline $\mathrm{X} 2$ & 100 & 25 & 50 & 40.60 & 5.228 \\
\hline $\mathrm{X} 3$ & 100 & 19 & 40 & 33.01 & 3.971 \\
\hline Y & 100 & 15 & 35 & 27.78 & 3.724 \\
\hline Valid N (listwise) & 100 & & & & \\
\hline
\end{tabular}

Sumber: Data primer diolah SPSS (2018)

Dapat dideskripsikan bahwa jumlah responden dalam penelitian ini $(\mathrm{N})$ yaitu sebanyak 100 sampel. Pada variabel pemahaman peraturan pajak hasil uji statistik deskriptif memiliki nilai minimum 24, nilai maximum 40, nilai rata - rata (mean) 33,33 dengan standar deviasi 3,668. Pada variabel pelayanan fiskus hasil uji statistik deskriptif memiliki nilai minimum 25 , nilai maximum 50 , rata - rata (mean) 40,60 dengan standar deviasi 5,228. Dan pada variabel pepersepsi efektivitas sistem perpajakan hasil uji statistik deskriptif memiliki nilai minimum 19, nilai maximum 40, rata - rata (mean) 33,01 dengan standar deviasi 3,971.

\subsection{Uji Asumsi Klasik}

\subsubsection{Uji Normalitas}

Uji normalitas dilakukan untuk melihat apakah dalam model regresi variabel terikat dan variabel bebas mempunyai distribusi data yang normal atau tidak. Uji Kolmogorov Smirnov data memiliki ketentuan Asymp. Sig > Alpha $(0,05)$, jika ketentuan ini telah terpenuhi berarti data tersebut telah terdistribusi secara normal. 
Tabel 2

Hasil Uji Normalitas secara Statistik

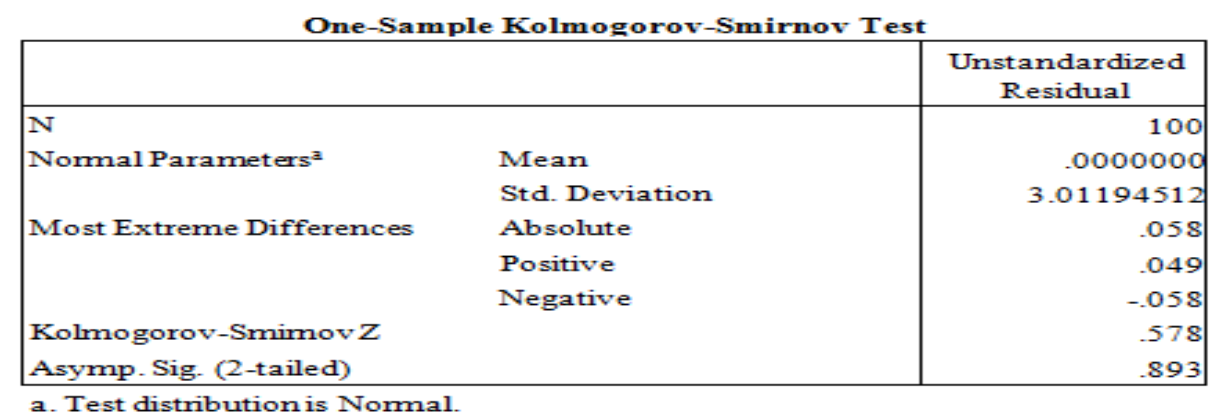

Sumber: Data primer diolah SPSS(2018)

Berdasarkan uji Kolmogorov - Smirnov dapat diketahui bahwa nilai Unstandardized Residual memiliki nilai (Asym.Sig 2-tailed) sebesar 0,893 yang berarti >0,05. Hasil ini menunjukkan bahwa semua data telah terdistribusi dengan normal.

\subsubsection{Uji Multikolinearitas}

Pengujian multikolinearitas dilakukan untuk mendeteksi adanya problem multikolinearitas atau tidak. Model uji regresi yang baik selayaknya tidak terjadi multikolinearitas. Jika nilai VIF kurang dari 10 dan nilai Tolerance lebih besar dari 0.10 maka tidak menimbulkan gejala multikolinearitas, yang artinya bahwa model regresi layak untuk dilakukan.

\section{Tabel 3}

\section{Hasil Uji Multikolinearitas}

\begin{tabular}{|c|c|c|c|}
\hline \multicolumn{4}{|c|}{ Coefficients $^{\mathrm{a}}$} \\
\hline \multirow{2}{*}{\multicolumn{2}{|c|}{ Model }} & \multicolumn{2}{|c|}{ Collinearity Statistics } \\
\hline & & Tolerance & VIF \\
\hline \multirow[t]{4}{*}{1} & (Constant) & & \\
\hline & Pemahaman Peraturan Pajak & .637 & 1.571 \\
\hline & Pelayanan Fiskus & .555 & 1.803 \\
\hline & $\begin{array}{l}\text { Persepsi Efektivitas Sistem } \\
\text { Perpajakan }\end{array}$ & .527 & 1.897 \\
\hline
\end{tabular}

Sumber: Data primer diolah SPSS(2018)

Dari hasil pengujian multikolinieritas dapat disimpulkan bahwa tidak terjadi multikolinearitas karena hasil uji nilai tolerance lebih besar dari 0,10 dan hasil uji VIF lebih kecil dari 10.

\subsubsection{Uji Heterokedastisitas}

Uji heteroskedastisitas dilakukan bertujuan untuk menguji apakah dalam model regresi terjadi ketidaksamaan variance dari residual satu pengamatan kepengamatan yang lain. Model regresi yang baik adalah yang tidak terjadi heteroskedastisitas. 


\section{Tabel 4}

\section{Hasil Uji Heterokedastisitas}

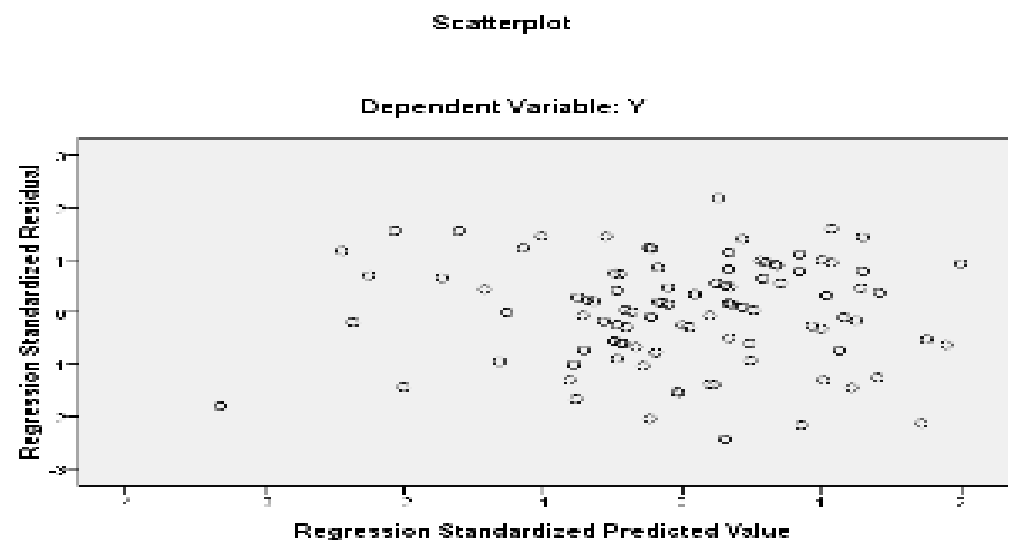

Sumber: Data primer diolah SPSS(2018)

Dari grafik scatterplot pada gambar dapat dilihat bahwa hasil pengujian menunjukkan titik titik pada gambar menyebar secara acak, serta tersebar dan tidak membentuk sebuah pola tertentu baik diatas maupun dibawah angka 0 (nol). Sehingga dapat disimpulkan bahwa tidak terjadinya heterokedastisitas pada model regresi.

\subsection{Analisis Regresi Linear Berganda}

Alat analisis yang digunakan untuk menguji hipotesis dalam penelitian ini adalah analisis regresi linear berganda. Analisis regresi linear berganda dilakukan agar dapat mengetahui arah hubungan antara variabel independen terhadap dependen.

\section{Tabel 5}

\section{Hasil Analisis Regresi Linear Berganda}

\begin{tabular}{|c|c|c|c|c|c|c|c|c|}
\hline \multicolumn{9}{|c|}{ Coefficients ${ }^{*}$} \\
\hline & & \multicolumn{2}{|c|}{$\begin{array}{c}\text { Unstandardized } \\
\text { Coefficients }\end{array}$} & \multirow{2}{*}{\begin{tabular}{|c|}
$\begin{array}{c}\text { Standardieed } \\
\text { Coefficients }\end{array}$ \\
Beta \\
\end{tabular}} & \multirow[b]{2}{*}{$\mathrm{t}$} & \multirow[b]{2}{*}{ Sig. } & \multicolumn{2}{|c|}{$\begin{array}{c}\text { Collinearity } \\
\text { Statistics }\end{array}$} \\
\hline \multicolumn{2}{|c|}{ Model } & B & Std. Error & & & & Tolerance & VIF \\
\hline 1 & (Constant) & 8.168 & 3.107 & & 2.629 & .010 & & \\
\hline & $\mathrm{X} 1$ & .106 & .105 & .104 & 1.010 & .315 & .637 & 1.571 \\
\hline & $\times 2$ & .332 & .079 & .466 & 4.206 & .000 & .555 & 1.803 \\
\hline & $\times 3$ & .079 & .107 & .084 & .738 & .462 & .527 & 1.897 \\
\hline
\end{tabular}

a. Dependent Variable: $Y$

Sumber: Data primer diolah SPSS(2018)

Berdasarkan hasil uji analisis regresi linear berganda diatas maka dapat disusun persamaan garis linear berganda sebagai berikut :

$$
Y=0,104 X 1+0,466 \times 2+0,84 X 3+e
$$


Pada hasil persamaan regresi linear berganda diatas menunjukkan hasil untuk nilai koefisien regresi dari ketiga variabel independen yang telah dianalisis dapat diketahui bahwa nilai koefisien regresi pada variabel pelayanan fiskus adalah yang paling besar dari ketiga variabel independen, hal ini menunjukkan bahwa variabel pelayanan fiskus memiliki kontribusi perubahan yang lebih besar dibandingkan kedua variabel lainnya.

\subsection{Uji Koefisien Determinasi}

Uji koefisien determinasi digunakan untuk menentukan seberapa besar variabel independen dapat menjelaskan variabel dependen dan untuk mengetahui persentase pengaruh variabel independen terhadap dependen. Maka untuk melihat adanya pengaruh tersebut perlu diketahui nilai koefisien determinasi (adjusted R-Square)

\section{Tabel 6}

Hasil Uji Koefisien Determinasi Model Summary ${ }^{\text {b }}$

\begin{tabular}{|l|c|r|r|r|}
\hline Model & $\mathrm{R}$ & R Square & Adjusted R Square & Std. Error of the Estimate \\
\hline 1 & $.588^{\mathrm{a}}$ & .346 & .326 & 3.059 \\
\hline
\end{tabular}

a. Predictors: (Constant), X3, X1, X2

b. Dependent Variable: Y

\section{Sumber: Data primer diolah SPSS(2018)}

Hasil pengujian pada tabel menunjukkan bahwa nilai koefisien determinasi ( $R$ Square) sebesar 0,346 dan nilai koefisien determinasi yang sudah disesuaikan (Adjusted $R$ Square) adalah sebesar 0,326 . Hal ini berarti hanya $32,6 \%$ dari variabel dependen kemauan membayar pajak bisa dijelaskan oleh ketiga variabel independen pemahaman peraturan pajak, pelayanan fiskus, dan persepsi efektivitas sistem perpajakan.

\subsection{Uji t (Uji Parsial)}

Uji statistik uji parsial t digunakan untuk menguji pengaruh dari masing - masing variabel independen secara parsial terhadap variabel dependen. Uji t juga berguna untuk mengetahui ada tidaknya pengaruh masing - masing variabel independen secara parsial terhadap variabel dependen yang dilihat pada tingkat signifikansi 0,05 .

1. Hasil Uji Hipotesis 1 : Pemahaman Peraturan Pajak Tidak Berpengaruh Terhadap Kemauan Membayar Pajak. Hasil uji hipotesis 1 menunjukkan nilai t hitung $<\mathrm{t}$ tabel $(1,010<1,660)$ dan nilai sig. $>$ nilai sig. tabel $(0,315>0,05)$. Hal ini berarti hasil hipotesis 1 tidak signifikan dan Ho diterima dan Ha ditolak.

2. Hasil Uji Hipotesis 2 : Pelayanan Fiskus Berpengaruh Terhadap Kemauan Membayar Pajak Hasil uji hipotesis 2 menunjukkan nilai t hitung $>$ t tabel $(4,206>1,660)$ dan nilai sig. $<$ nilai sig. tabel $(0,000<0,05)$. Hal ini berarti hasil hipotesis 2 signifikan dan Ho ditolak dan Ha diterima sehingga dapat dikatakan bahwa variabel pelayanan fiskus (X2) "berpengaruh signifikan" terhadap kemauan membayar pajak (Y).

3. Hasil Uji Hipotesis 3 : Persepsi Efektivitas Sistem Perpajakan Tidak Berpengaruh Terhadap Kemauan Membayar Pajak. Hasil uji hipotesis 3 menunjukkan nilai $\mathrm{t}$ hitung $<\mathrm{t}$ tabel $(0,738<$ $1,660)$ dan nilai sig. $>$ nilai sig. Tabel $(0,462>0,05)$. Hal ini berarti hasil hipotesis 3 tidak 
signifikan dan Ho diterima dan Ha ditolak sehingga dapat dikatakan bahwa variabel persepsi efektivitas sistem perpajakan (X3) "tidak berpengaruh signifikan" terhadap kemauan membayar pajak (Y).

\subsection{Pembahasan Hasil Pengujian Hipotesis}

\subsubsection{Pengaruh Pemahaman Peraturan Pajak Terhadap Kemauan Membayar Pajak}

Variabel pemahaman peraturan pajak menunjukkan hasil bahwa "tidak berpengaruh" terhadap kemauan membayar pajak dengan nilai signifikansi 0,315 lebih besar dari alpha 0,05. Hasil penelitian ini sejalan dengan hasil penelitian terdahulu yang dilakukan oleh Hardiningsih \& Yulianawati (2011) dan Priscilla (2016) yang menyatakan pemahaman peraturan perpajakan tidak berpengaruh terhadap kemauan membayar pajak.

Penerapan teori atribusi yang digunakan dalam penelitian ini cukup mampu menjelaskan tentang perilaku dari para responden mengenai faktor - faktor yang menyebabkan pemahaman peraturan pajak menjadi tidak berpengaruh terhadap kemauan membayar pajak. Dari teori yang dimaksud berhubungan dengan sikap dan karakter individu yang kurang paham mengenai peraturan pajak sehingga terjadi pengaruh yang menyebabkan kemauan membayar pajak menajadi minim. Hal ini terkait motif tentang perilaku wajib pajak yang menjadi objek dalam penelitian di KPP Pratama Jayapura.

Penelitian yang dilakukan di KPP Pratama Jayapura dapat diketahui jika mayoritas responden di KPP Pratama Jayapura belum terlalu memahami mengenai tentang peraturan perpajakan. Hal ini dapat dilihat dari hasil pengujian data dari para responden yang menunjukkan hasil pengujian validitas pada indikator pernyataan ke empat memiliki nilai terendah diantara ke delapan item pernyataan lainnya. Indikator pada pernyataan ke empat membahas tentang wajib pajak yang harus mengetahui hak sebagai wajib pajak. Jadi dapat disimpulkan bahwa para wajib pajak belum terlalu paham mengenai haknya sebagai wajib pajak, sehingga menimbulkan akibat terjadinya kemauan membayar pajak menjadi tidak berpengaruh.

Beberapa faktor lain yang mungkin dapat mempengaruhi hasil dari hipotesis pemahaman peraturan pajak terhadap kemauan membayar pajak diantaranya seperti pada penelitian oleh Hardiningsih \& Yulianawati (2011) dan Priscilla (2016) yang dalam penelitiannya menyimpulkan adanya indikasi bahwa sebagian besar pendidikan wajib pajak menjadi faktor yang menyebabkan kurangnya pengetahuan tentang peraturan pajak, sehingga pemahaman tentang peraturan pajak menjadi minim dan sangat kurang. Dari hasil penelitian yang dilakukan di KPP Pratama Jayapura dapat diketahui jika mayoritas responden di KPP Pratama Jayapura belum terlalu memahami mengenai tentang peraturan perpajakan. Namun hasil dari data responden menunjukkan bahwa pendidikan yang ditempuh oleh wajib pajak di KPP Pratama Jayapura sudah cukup baik dengan tingkat pendidikan yang tergolong tinggi yaitu 49 responden dari 100 responden memiliki jenjang pendidikan Strata Satu (S1). Namun hal ini tidak menjamin pemahaman wajib pajak mengenai peraturan pajak.

Harapannya dalam hal ini, menjadi kewajiban dan tugas tambahan bagi para petugas pajak serta pihak terkait untuk lebih meningkatkan dan menambah wawasan bagi masyarakat luas mengenai peraturan pajak dengan cara seperti pengajaran, pelatihan ataupun tambahan penjelasan tentang peraturan perpajakan melalui sosialisasi atau training yang dilakukan oleh Dirjen Pajak ataupun Kantor Pajak terkait. 


\subsubsection{Pengaruh Pelayanan Fiskus Terhadap Kemauan Membayar Pajak}

Variabel pelayanan fiskus menunjukkan hasil bahwa "berpengaruh" terhadap kemauan membayar pajak dengan nilai signifikansi 0,000 lebih kecil dari alpha 0,05. Hasil penelitian ini sejalan dengan hasil penelitian yang dilakukan oleh Hardiningsih \& Yulianawati (2011), Fikriningrum \& Syafruddin (2012), Nuzul (2015), Priscilla (2016), dan Manuaba \& Gayatri (2017) yang menyatakan pelayanan fiskus berpengaruh terhadap kemauan membayar pajak.

Berdasarkan hasil yang didapat menunjukkan sikap wajib pajak sudah cukup memiliki kepercayaan terhadap pelayanan yang cukup baik dari aparatur pajak. Kualitas pelayanan yang baik dari instansi pajak menjadi modal yang cukup besar untuk menarik minat dan perhatian dari para wajib pajak. Maka diharapkan agar pelayanan yang berkualitas dari para aparatur pajak agar tetap dipertahankan sehingga wajib pajak sampai bahkan masyarakat terus percaya dengan kinerja yang diberikan Kantor Pelayanan Pajak maupun Dirjen Pajak sehingga kemauan membayar pajak semakin meningkat. Dengan semakin tingginya pelayanan fiskus maka akan semakin tinggi pula kemauan wajib pajak untuk membayarkan pajaknya.

\subsubsection{Pengaruh Persepsi Efektivitas Sistem Perpajakan Terhadap Kemauan Membayar Pajak}

Variabel persepsi efektivitas sistem perpajakan menunjukkan hasil bahwa "tidak berpengaruh" terhadap kemauan membayar pajak dengan nilai signifikansi 0,462 lebih besar dari alpha 0,05. Hasil penelitian ini sejalan dengan hasil penelitian yang dilakukan oleh Hardiningsih \& Yulianawati (2011), Wijaya. RM. Sayid Fiska Kusuma (2014), dan Priscilla (2016) yang menyatakan persepsi efektivitas sistem perpajakan tidak berpengaruh terhadap kemauan membayar pajak.

Penelitian yang dilakukan di KPP Pratama Jayapura menunjukkan hasil bahwa mayoritas wajib pajak belum menganggap bahwa sistem perpajakan saat ini sudah efektif. Hal ini dapat dilihat dari hasil pengujian data dari para responden yang menunjukkan hasil pengujian validitas pada indikator pernyataan ke enam memiliki nilai terendah di antara ke delapan item pernyataan yang menjadi instrument dalam penelitian ini. Indikator pada pernyataan ke enam terkait pengaksesan peraturan pajak melalui internet. Jadi dapat disimpulkan bahwa sarana pengaksesan peraturan pajak melalui internet masih tergolong rendah dan kurang baik untuk dijadikan sarana sosialisasi bagi para wajib pajak, sehingga menyebabkan anggapan bahwa sistem perpajakan saat ini masih kurang efektif.

Beberapa faktor lain yang mungkin dapat mempengaruhi sehingga hasil dari hipotesis persepsi efektivitas sistem perpajakan terhadap kemauan membayar pajak diantaranya seperti pada penelitian oleh Hardiningsih \& Yulianawati (2011), Wijaya. RM. Sayid Fiska Kusuma (2014), dan Priscilla (2016) menjelaskan bahwa tidak terjadinya pengaruh dari persepsi efektifitas sistem perpajakan terhadap kemauan membayar pajak karena cara penyampaian yang dilakukan dalam sistem efektivitas pajak yang kurang menarik atau kurang diketahui oleh wajib pajak. Dari hasil penelitian yang dilakukan di KPP Pratama Jayapura menunjukkan hasil bahwa wajib pajak mengenggap bahwa efektifitas sistem perpajakan saat ini belum terlalu baik. Dari hasil ini dilihat faktor yang menyebabkan terjadinya hal tersebut adalah terkait kemajuan teknologi yang kurang dimanfaatkan baik oleh wajib pajak. Kemajuan teknologi dan sumber informasi yang semakin mudah didapat oleh masyarakat melalui internet dan sosial media kurang dioptimalkan untuk memperbarui pengetahuan mengenai peraturan pajak, hal inilah yang menyebabkan kurangnya pemahaman peraturan pajak sehingga tidak menjamin seorang wajib pajak akan lebih menyadari tentang pentingnya membayar pajak.

Sistem perpajakan saat ini sebenarnya sudah cukup efektif terbukti dengan adanya berbagai proram yang memudahkan pelaporan dan pelunasan pajak bagi wajib pajak seperti e-SPT, e-Filling, 
e-Banking, penyampaian SPT via drop box, dan pendaftaran NPWP secara online yang dapat dengan mudah diakses tanpa harus repot pergi ke kantor pelayanan pajak. Namun, hal ini kurang diminati oleh wajib pajak sebab wajib pajak kurang paham dan mengerti mengenai fasilitas program online yang disediakan ini. Dari hasil penelitian yang dilakukan dilapangan menunjukkan bahwa wajib pajak masih ragu dan kurang percaya pada program tersebut bahkan ada pula yang tidak mengetahui dan lebih memilih langsung membayarkan pajaknya ke kantor.

Berdasarkan kasus tersebut masih diperlukan beberapa perbaikan agar sistem perpajakan berjalan lebih baik lagi. Solusi dari kasus ini terkait penyampaian atau promosi yang dilakukan dalam sistem perpajakan harus lebih menarik agar dapat diketahui secara luas. Maka tugas dari aparatur pajak adalah harus lebih intensif untuk menarik wajib pajak agar mau membayar kewajiban perpajakannya. Langkah - langkah yang dapat dilakukan contohnya seperti pemberitahuan via internet atau sosial media, spanduk, baliho, dan iklan media elektronik.

Dalam kaitanya dengan persepsi efektivitas sistem perpajakan, kondisi seperti ini akan berpengaruh pada kemauan para wajib pajak yang rendah dalam membayar pajak. Adanya persepsi yang baik dari wajib pajak sangat penting untuk meningkatkan efektivitas sistem perpajakan. Dalam prakteknya apabila efektifitas sistem perpajakan tidak memberikan hasil terbaiknya untuk mempermudah masyarakat sebagai wajib pajak dalam melaksanakan kewajiban perpajakannya, tentu akan menimbulkan kesenggangan dan persepsi yang kurang baik dari wajib pajak sehingga dapat menurunkan tingkat kemauan membayar pajak.

Dengan menerapkan sistem perpajakan yang lebih memudahkan wajib pajak dan meningkatkan persepsi yang baik dari wajib pajak diharapkan akan dapat mendorong kemauan wajib pajak dalam membayar iuran pajaknya kepada negara.

\section{PENUTUP}

\subsection{Kesimpulan}

Penelitian ini bertujuan untuk mengetahui bahwa pemahaman peraturan pajak, pelayanan fiskus, dan persepsi efektivitas sistem perpajakan berpengaruh terhadap kemauan membayar pajak. Dalam penelitian ini menggunakan 100 sampel penelitian dari responden di KPP Pratama Jayapura. Berdasarkan data yang telah dikumpulkan dan dari hasil penelitian serta pembahasan permasalahan pada setiap variabel dengan menggunakan model analisis regresi berganda, maka dapat disimpulkan

1. Variabel pemahaman peraturan perpajakan tidak berpengaruh signifikan terhadap kemauan membayar pajak.

2. Variabel pelayanan fiskus berpengaruh signifikan terhadap kemauan membayar pajak

3. Variabel persepsi efektivitas sistem perpajakan tidak berpengaruh signifikan terhadap kemauan membayar pajak.

4. Berdasarkan hasil pengujian koefisien determinasi menunjukkan nilai 0,326 yang berarti bahwa 32,6\% variabel kemauan membayar pajak dipengaruhi oleh variabel pemahaman peraturan perpajakan, pelayanan fiskus, dan persepsi efektivitas sistem perpajakan, sedangkan sisanya sebesar $67,4 \%$ dapat dijelaskan oleh faktor-faktor dari variabel lain yang mempengaruhi variabel kemauan membayar pajak.

\subsection{Keterbatasan Penelitian}

Adapun keterbatasan dalam penelitian ini yang perlu di perhatikan untuk peneliti selanjutnya antara lain :

1. Penelitian ini yang hanya dilakukan pada salah satu kantor pelayanan pajak yaitu KPP Pratama Jayapura. 
2. Penelitian ini hanya menggunakan tiga variabel yang mempengaruhi kemauan membayar pajak, padahal masih ada kemungkinan variabel lain yang dapat mempengaruhi kemauan membayar pajak.

3. Pengumpulan data berupa kuesioner yang kurang optimal karna pengisian oleh responden yang sedang melakukan aktivitas perpajakan, sehingga data yang dikumpulkan kurang maksimal dalam pengisian angket kuesionernya.

4. Keterbatasan waktu dalam melakukan penelitian sehingga mengakibatkan peneliti tidak bisa mendapatkan hasil secara maksimal.

\subsection{Saran}

Dari kesimpulan di atas maka penulis dapat memberikan beberapa saran sebagai berikut :

1. Pemerintah dan aparatur pajak hendaknya agar lebih intensif dalam memberikan informasi mengenai peraturan pajak, tata cara perpajakan, serat informasi lainnya mengenai pajak yang melibatkan masyarakat sebagai wajib pajak.

2. Pelayanan yang terbaik dari aparatur pajak dan pemerintah serta kemudahan yang diberikan kepada wajib pajak untuk mempermudah wajib pajak dalam menjalankan kewajiban perpajakan haruslah semakin ditingkatkan agar kedepan kemauan membayar pajak semakin tinggi

3. Untuk penelitian selanjutnya diharapkan untuk memperluas ruang lingkup penelitian di daerah lain, sehingga dapat memperoleh sampel yang lebih banyak.

4. Untuk penelitian selanjutnya agar melakukan penambahan variabel lain seperti kesadaran dan tingkat kepercayaan yang telah dilakukan di penelitian - penelitian sebelumnya yang mampu mepengaruhi dan menjelaskan mengenai kemauan membayar pajak sehingga memperoleh hasil yang lebih baik lagi. 


\section{DAFTAR PUSTAKA}

Fikriningrum, W. K., \& Syafruddin, M. (2012). Analisis faktor-faktor yang mempengaruhi wajib pajak orang pribadi dalam memenuhi kewajiban membayar pajak( studi kasus pada kantor pelayanan pajak pratama Semarang Candisari ). Diponegoro Journal Of Accounting, 1(2), 1-15.

Fitriana, S. (2012). Pengaruh Pemahaman Tentang Peraturan Perpajakan, Persepsi Efektivitas Sistem Perpajakan Dan Tingkat Kepercayaan Sistem Perpajakan Dan Tingkat Kepercayaan Sistem Pemerintahan Dan Hukum Terhadap Kemauan Membayar Pajak Wajib Pajak Orang Pribadi Yang Melakuka, 1-15.

Hardiningsih, P., \& Yulianawati, N. (2011). Faktor-Faktor Yang Mempengaruhi Kemauan Membayar Pajak. Dinamika Keuangan Dan Perbankan, 3(1), 126-142. https://doi.org/ISSN: $1979-4878$

Huda, A. (2015). Pengaruh Persepsi atas Efektifitas Sistem Perpajakan, Kepercayaan, Tarif Pajak Dan Kemanfaatan NPWP terhadap Kepatuhan Membayar Pajak (Studi Empiris Pada Wajib Pajak Umkm Makanan dii KPP Pratama Pekanbaru Senapelan). Jom FEKON, 2(2), 1-15.

Luthans, F., Avolio, B. J., Walumbwa, F. O., \& Li, W. (2005). The Psychological Capital of Chinese Workers : Exploring the Relationship with Performance Fred Luthans, Bruce J . Avolio, Fred O . Walumbwa. Management and Organization Review, 1(2), 249-271.

Manuaba, I. A. C. A., \& Gayatri. (2017). E-Jurnal Akuntansi Universitas Udayana Fakultas Ekonomi dan Bisnis Universitas Udayana ( Unud ), Bali , Indonesia Fakultas Ekonomi dan Bisnis Universitas Udayana ( Unud ), Bali, Indonesia ABSTRAK Pembangunan merupakan kewajiban negara yang dilaksanakan $\mathrm{u}, 19,1259-1289$.

Mardiasmo. 2008 . Perpajakan Edisi Revisi 2008. Yogyakarta: CV Andi Offset.

Mardiasmo. 2009 . Perpajakan Edisi Revisi 2009. Yogyakarta: CV Andi Offset.

Mardiasmo. 2011. Perpajakan Edisi Revisi 2011. Yogyakarta : CV Andi Offset

Newcomb, T., \& Heider, F. (1958). The Psychology of Interpersonal Relations. American Sociological Review, 23(6), 742. https://doi.org/10.2307/2089062

Nurlaela, S. (2014). Pengaruh pengetahuan dan pemahaman, kesadaran, persepsi terhadap kemauan membayar pajak wajib pajak orang pribadi yang melakukan pekerjaan bebas. Jurnal Paradigma, 11(16930827), 89-101.

Nuzul, A. V. (2015). Analisis Pengaruh Efektifitas Sistem Perpajakan, Pemahaman, Tingkat Kepercayaan Pada Sistem Pemerintahan Dan Hukum, Kualitas Pelayanan Pajak Terhadap Willingness To Pay Taxes.

Priscilla, F. (2016). Pengaruh Kesadaran, Pemahaman, Persepsi, Tingkat Kepercayaan Dan Kualitas Pelayanan Terhadap Kemauan Membayar Pajak.

Ratung, T., \& Adi, P. H. (2009). Dampak Program Sunset Policy terhadap Faktor-Faktor yang Mempengaruhi Kemauan Membayar Pajak. Simposium Nasional Perpajakan II, 1-28.

Retno Yuni Kurniawati. (2011). "Hubungan Antara Persepsi Siswa Tentang Metode Mengajar Guru Dan Minat Belajar Dengan Prestasi Belajar Akuntansi Siswa Kelas X Kompetensi Keahlian Akuntansi SMK Negeri 1 Godean Tahun Ajaran 2010/2011. Skripsi. Fakultas Ekonomi. Universitas Negeri Yogyakarta.

Robins, R. W., Spranca, M. D., \& Mendelsohn, G. A. (1996). The actor-observer effect revisited: Effects of individual differences and repeated social interactions on actor and observer attributions. Journal of Personality and Social Psychology, 71(2), 375-389. https://doi.org/10.1037/0022-3514.71.2.375 
Soemitro, Rochmat. 1965. Dasar-dasar Hukum Pajak dan Pajak Pendapatan. Bandung : Eresco

Sulastri, P. (2015). Akuntansi Keperilakuan Terhadap Pengembangan Akuntansi Manajemen. DHARMA EKONOMI, 16. Retrieved from ejurnal.stiedharmaputra-smg.ac.id

Widaningrum, Dwi Indah. 2007. "Identifikasi Kemampuan dan Kemauan Membayar Masyarakat Berpenghasilan Menengah rendah (Di Lokasi Rencana Pembangunan Rumah Susun Tamansari Kota Bandung)". Tugas Akhir. Diambil dari: www.sappk.itb.ac.id pada 11 Mei 2014.

Widayati dan Nurlis. 2010. "Faktor-Faktor Yang Mempengaruhi Untuk Membayar Pajak Wajib Pajak Orang Pribadi Yang Melakukan Pekerjaan Bebas Studi Kasus Pada KPP Pratama Gambir Tiga”. Proceeding Simposium Nasional Akuntansi XII. Purwokerto

Wijaya. RM. Sayid Fiska Kusuma. (2014). Faktor - Faktor Yang Mempengaruhi Kemauan Untuk Membayar Pajak Wajib Pajak Orang Pribadi Yang Melakukan Pekerjaan Bebas (Studi Kasus Pada KPP Pratama Karanganyar. 